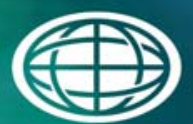

Savannah River

National Laboratory "m

OPERATED BY SAVANNAH RIVER NUCLEAR SOLUTIONS

\title{
Artifact Formation During Neutralization of Tank 50 Samples
}

S. L. Crump

J. E. Young

August 2014

SRNL-ST1-2014-00088, Revision 0 


\section{DISCLAIMER}

This work was prepared under an agreement with and funded by the U.S. Government. Neither the U.S. Government or its employees, nor any of its contractors, subcontractors or their employees, makes any express or implied:

1. warranty or assumes any legal liability for the accuracy, completeness, or for the use or results of such use of any information, product, or process disclosed; or

2. representation that such use or results of such use would not infringe privately owned rights; or

3. endorsement or recommendation of any specifically identified commercial product, process, or service.

Any views and opinions of authors expressed in this work do not necessarily state or reflect those of the United States Government, or its contractors, or subcontractors.

\section{Printed in the United States of America \\ Prepared for U.S. Department of Energy}


Keywords: Tank $50-H$

pH Adjustment

Gas Chromatograph / Mass

Spectrometer (GC/MS)

Retention: Permanent

\title{
Artifact Formation During Neutralization of Tank 50 Samples
}

\author{
S. L. Crump \\ J. E. Young
}

August 2014

Prepared for the U.S. Department of Energy under 


\section{REVIEWS AND APPROVALS}

\section{AUTHORS:}

S. L. Crump, Analytical Development

Date

J. E. Young, Analytical Development

Date

TECHNICAL REVIEW:

C. J. Bannachie, Process Technology Programs, (Reviewed per E7 2.60)

Date

APPROVAL:

L. H. Connelly, Manager

Date

Spectroscopy,Separations \& Log

M. J. Barnes, Manager

Date

Analytical Development

E. N. Hoffman, Manager

Date

Engineering Prtocess Development

S.L. Marra, Manager

Date

Environmental \& Chemical Process Technology Research Programs 


\section{EXECUTIVE SUMMARY}

Degradation products have been identified in the extracts of Tank 50 samples analyzed by semivolatile organic compound analysis (SVOA) using gas chromatography/mass spectrometry (GC/MS). These materials, identified as short chain alkyl alcohols, were formed by acidification during sample preparation. A number of questions were raised about the formation of these and other materials reported in Tank 50 surface samples, and this report serves to address these questions. In summary the questions and answers are as follows.

Q1. Is the isooctyl adipate, reported in the $3 \mathrm{Q} 12$ and $4 \mathrm{Q} 12$ samples of Tank 50, connected to the other organics generated by the acidification of SVOA prep?

A1. No, the adipate plasticizer is a highly functionalized molecule.

Q2. What is the source of the six carbon chain organic that is being converted to 4-methyl-3hexanol and/or 5-methyl-3-hexanol?

A2. Alcohols were generated as degradation products from the action of nitrous acid (formed in situ) on phenol-d6 surrogate and other laboratory standards.

Q3. Are the degradation products found in the sample extracts added to the SVOA prep as standards? How are the lab standards playing a role in the artifact formation?

A3. Experimentation has shown that the organic impurities identified in the Tank 50 sample extracts were formed by the action of nitrous acid on laboratory standards. The compounds were not added directly, but were formed during preparation of samples.

Q4. What is the result of NMR spectra of the methylene chloride extractant? Does it show the presence of hexane contamination?

A4. Impurities are present in the methylene chloride at the low ppm level. Hexane was not found, and the impurities identified do not contribute significantly to the organic mass associated with the Tank 50 extract. 


\section{TABLE OF CONTENTS}

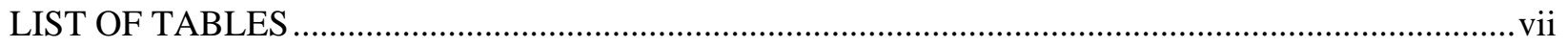

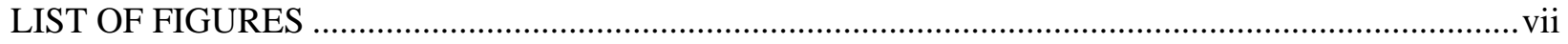

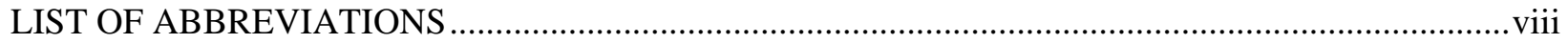

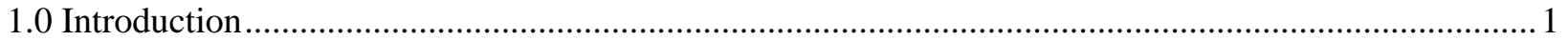

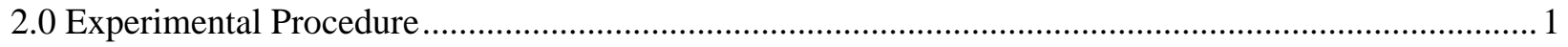

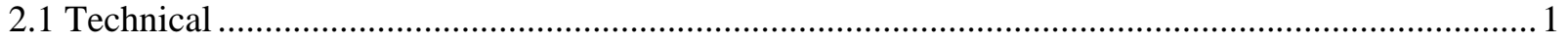

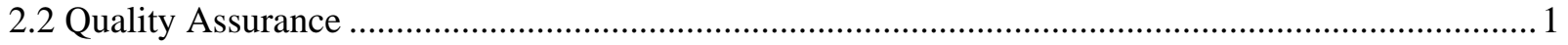

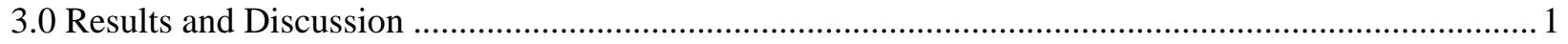

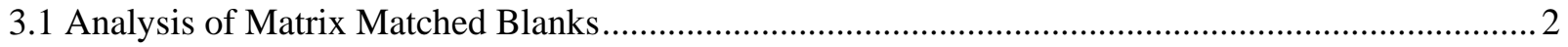

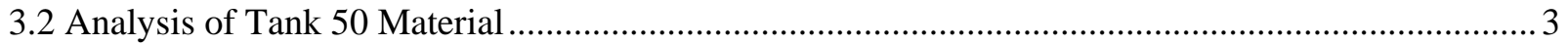

3.3 NMR Analysis of Solvents Used for Preparation of Samples....................................................... 4

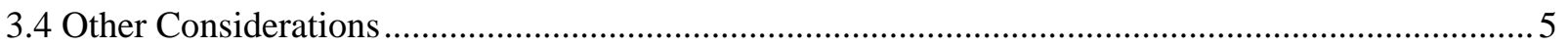

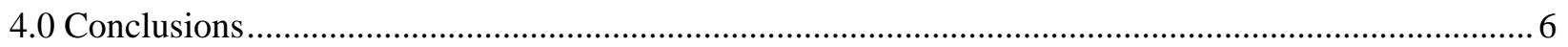

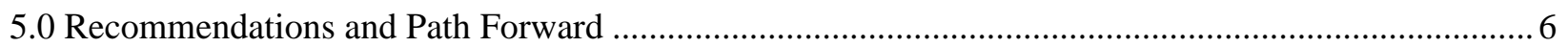

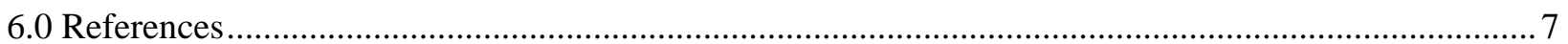




\section{LIST OF TABLES}

Table 3-1. Organic Constituents Associated with SVOC Sample Preparation. .5

\section{LIST OF FIGURES}

Figure3-1. Chromatographic Results of the Matrix Matched Blank Prepared at Varied pH Levels. .......... 3

Figure 3-2. Comparison of chromatograms from acid adjusted simulant analysis with acidified Tank 50 sample.

Figure 3-3. NMR Spectrum of Impurities Present in Methylene Chloride Extractant 5 


\section{LIST OF ABBREVIATIONS}

$\begin{array}{ll}\text { GC/MS } & \text { Gas Chromatography/Mass Spectrometry } \\ \text { ISS } & \text { Internal Standard Solution } \\ \text { NMR } & \text { Nuclear Magnetic Resonance Spectroscopy } \\ \text { RT } & \text { Retention Time } \\ \text { SRNL } & \text { Savannah River National Laboratory } \\ \text { SRS } & \text { Savannah River Site } \\ \text { SVOA } & \text { Semivolatile Organic Compound Analysis }\end{array}$




\subsection{Introduction}

The action of nitrous acid, formed by the over-acidification of the Tank 50 surface sample matrix to $\mathrm{pH} 2$, caused the formation of degradation products in the Tank 50 sample extracts. Acidification to $\mathrm{pH} 7$ or less is necessary to protonate phenolate ions present in the sample to affect extraction and subsequent analysis of phenol by semi-volatile organic analysis (SVOA); further acidification is not required.

This report serves to address artifact formation during preparation of the Tank 50 surface samples, and in doing so will also serve to address the following questions related to the preparation and analysis of these samples in recent quarters.

1. Is the isooctyl adipate, reported in the $3 \mathrm{Q} 12$ and $4 \mathrm{Q} 12$ samples of Tank 50, connected to the other organics generated by the acidification of the SVOA prep?

2. What is the source of the six carbon chain organic that is being converted to 4-methyl-3-hexanol and/or 5-methyl-3-hexanol?

3. Are the degradation products found in the organic materials added to the SVOA prep as standards playing any role in the erroneous reporting?

4. What is the result of an NMR spectrum of the methylene chloride extractant? Does it show the presence of hexane contamination?

\subsection{Experimental Procedure}

\section{$2.1 \underline{\text { Technical }}$}

Tank 50 sample preparation instructions for SVOA are as follows.

1. Measure $10 \mathrm{~mL}$ volume of sample.

2. The customer supplied blank must have all reagents added in the same amounts as used for the samples.

3. Spike with $50 \mu \mathrm{L}$ of $2000 \mathrm{mg} / \mathrm{L}$ Phenol-d6.

4. Mix, then measure $\mathrm{pH}$.

5. Add $5 \mathrm{~mL}$ saturated $\mathrm{KH}_{2} \mathrm{PO}_{4}$ buffer solution.

6. Add $5 \mathrm{M} \mathrm{H}_{3} \mathrm{PO}_{4}$ to lower $\mathrm{pH}$ (must be between 6 and 7).

7. Extract three times with $\mathrm{CH}_{2} \mathrm{Cl}_{2}$.

8. Combine $\mathrm{CH}_{2} \mathrm{Cl}_{2}$ layers and filter through glass wool and anhydrous $\mathrm{Na}_{2} \mathrm{SO}_{4}$ into clean vial.

9. Concentrate under $\mathrm{N}_{2}$ stream at room temperature to $1 \mathrm{~mL}$.

10. Spike with $20 \mu \mathrm{L}$ SVOA-ISS

\subsection{Quality Assurance}

Requirements for performing reviews of technical reports and the extent of review are established in manual E7 2.60. SRNL documents the extent and type of review using the SRNL Technical Report Design Checklist contained in WSRC-IM-2002-00011, Rev. 2.

\subsection{Results and Discussion}

SVOA is performed on a quarterly basis for Tank 50 surface samples at the Savannah River Site (SRS) with careful monitoring of phenol, tri-n-butyl phosphate, Isopar-L, and Norpar. 
Extraction of phenol during sample preparation requires acidification of the sample matrix to $\mathrm{pH} 7 \mathrm{prior}$ to extraction. Phenols are more acidic than organic alcohols, and the protonation equilibria for these species are shown in Equation (1) and (2) below. ${ }^{2}$

(1)

$$
\mathrm{CH}_{3} \mathrm{CH}_{2} \stackrel{\ddot{\mathrm{O}}-}{\mathrm{H}} \mathrm{H} \rightleftharpoons \mathrm{H}^{+}+\mathrm{CH}_{3} \mathrm{CH}_{2} \ddot{\mathrm{O}}: \quad \mathrm{K}_{\mathrm{a}}=10^{-16}\left(\mathrm{pK}_{\mathrm{a}}=16\right)
$$

Ethanol Proton Ethoxide ion

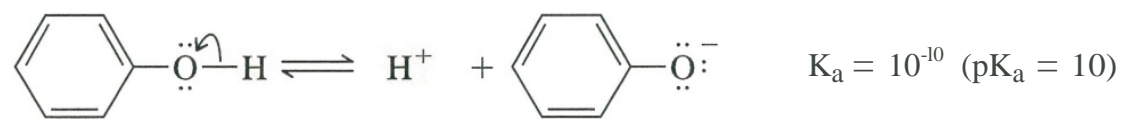

(2)

$$
\text { Phenol Proton Phenoxide }
$$

The negative charge on the phenoxide ion in Equation 2 is stabilized both by solvation and by electron delocalization into the aromatic ring. Electron delocalization in phenoxide causes stabilization of the ion, and this makes phenol a stronger acid than either the simple alcohols, such as ethanol, or the short chain alkyl alcohols that have been reported, which have no such stabilization.

The sample matrix contains sodium nitrite, which forms nitrous acid if the sample is acidified to $\mathrm{pH} 2$ or lower. Nitrous acid is a strong oxidant which reacts with organic compounds ${ }^{3}$ present in the sample or extract. The samples need not be acidified below pH 7.0 for extraction of phenol.

\subsection{Analysis of Matrix Matched Blanks}

We have demonstrated that acidification to $\mathrm{pH} 1.5$ of a matrix matched blank causes the same degradation products to form using identical preparative conditions. In Figure 3-1, overlaid traces are shown, depicting four chromatograms. The inverted black trace is a laboratory blank, showing six internal standards and a surrogate standard. The blue, red, and green traces above the blank are salt solution simulant extracted at $\mathrm{pH} 14,7$, and 1.5, respectively. 
Figure 3-1. Chromatographic Results of the Matrix Matched Blank Prepared at Varied pH Levels.

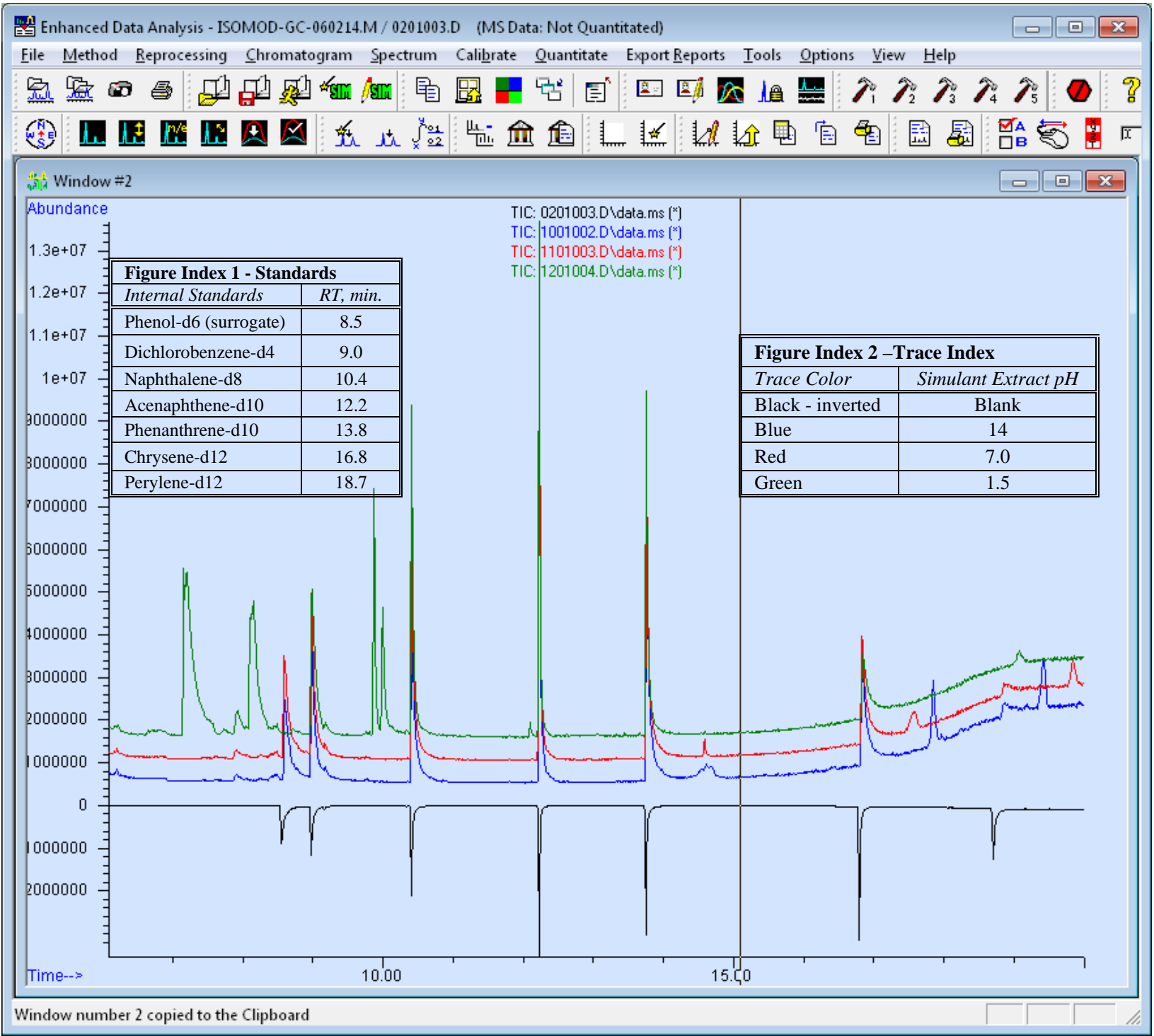

Note that impurities form at a retention time (RT) 8.0 minutes and lower as the $\mathrm{pH}$ is reduced. At $\mathrm{pH}$, no such impurities are formed. At pH 1.5 impurities form in the extract near RT 8.0 and also near RT 10.0, with concurrent disappearance of phenol-d6 at 8.5 minutes, as well as the sixth internal standard, perylene-d12, at 18.7 minutes.

\subsection{Analysis of Tank 50 Material}

Analysis of the matrix matched blank at $\mathrm{pH} 1.5$ resulted in a chromatogram virtually identical to those from the Tank 50 samples which were acidified to similar $\mathrm{pH}$ values during preparation. Figure 3-2 illustrates the similarity of these chromatograms. 


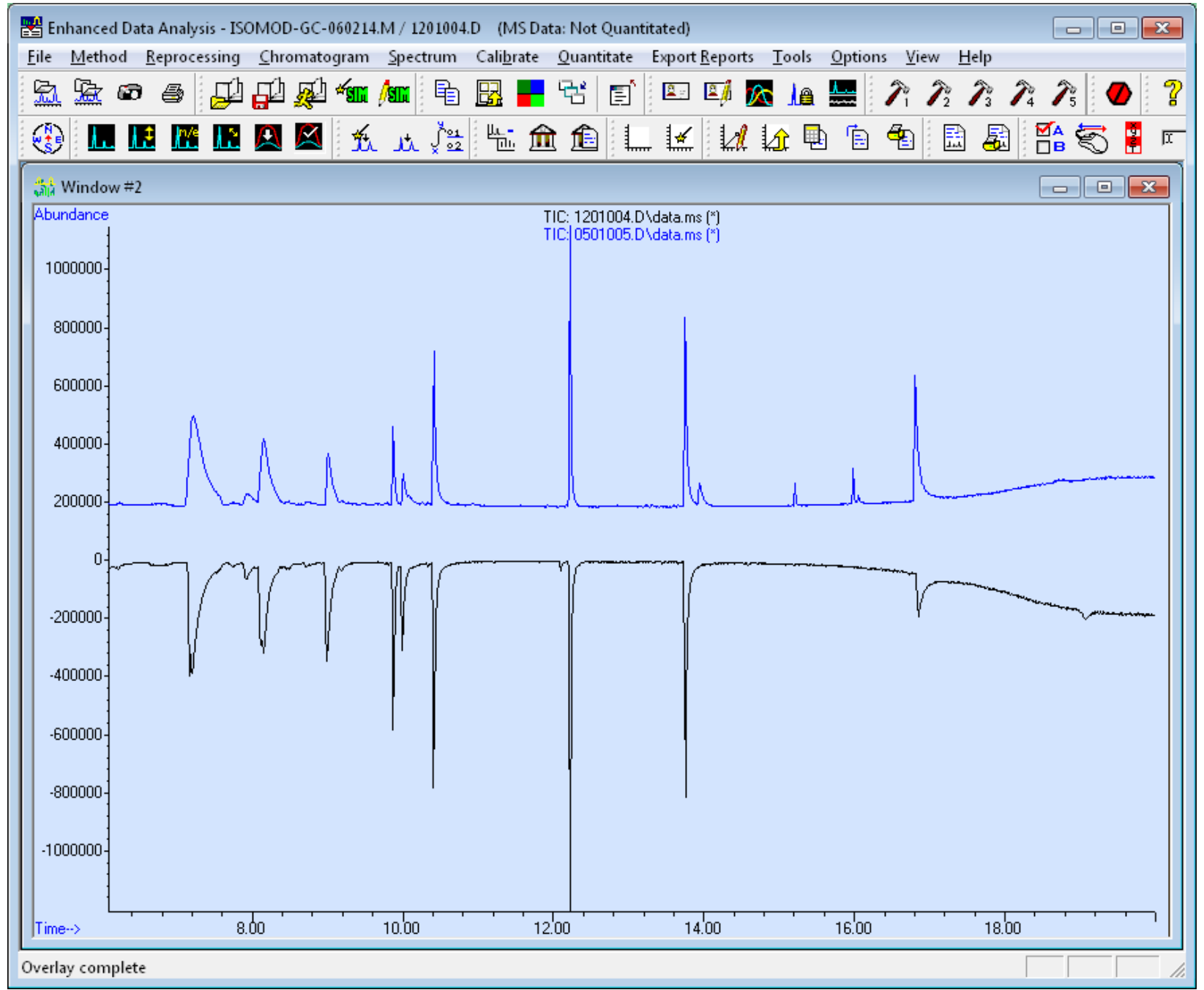

Figure 3-2. Comparison of chromatograms from acid adjusted simulant analysis (bottom trace) with acidified Tank 50 sample (top trace). Note: The impurity peaks at RT 10.0, 8.0, and lower are very similar.

\subsection{NMR Analysis of Solvents Used for Preparation of Samples}

Nuclear magnetic resonance (NMR) analysis results indicated that about $30 \mathrm{ppm}$ of hydrocarbon or alkylated material is in the $99.9 \%$ pure methylene chloride and about half of this material is water. This is consistent with our expectations. The identifiable protons present were from cyclohexanone, acetone, dimethyl acetamide, and possibly an allyl compound. The presence of impurities in the methylene chloride does not contribute significantly to the organic mass associated with the organic extract of the Tank 50 sample. The components are tabulated in Table 3-1 and shown in Figure 3-3 
Table 3-1. Organic Constituents Associated with SVOC Sample Preparation

\begin{tabular}{|c|c|c|}
\hline Constituent & Purpose & Concentration \\
\hline methylene chloride & Extractant & $90+\%$ \\
\hline isopropanol & Surrogate Solvent & $5 \%$ \\
\hline phenol-d6 & Surrogate & $100 \mathrm{mg} / \mathrm{L}$ \\
\hline dichlorobenzene-d4 & Internal Standard & $40 \mathrm{mg} / \mathrm{L}$ \\
\hline naphthalene-d8 & Internal Standard & $40 \mathrm{mg} / \mathrm{L}$ \\
\hline acenaphthene-d10 & Internal Standard & $40 \mathrm{mg} / \mathrm{L}$ \\
\hline phenanthrene-d10 & Internal Standard & $40 \mathrm{mg} / \mathrm{L}$ \\
\hline chrysene-d12 & Internal Standard & $40 \mathrm{mg} / \mathrm{L}$ \\
\hline perylene-d12 & Internal Standard & $40 \mathrm{mg} / \mathrm{L}$ \\
\hline
\end{tabular}

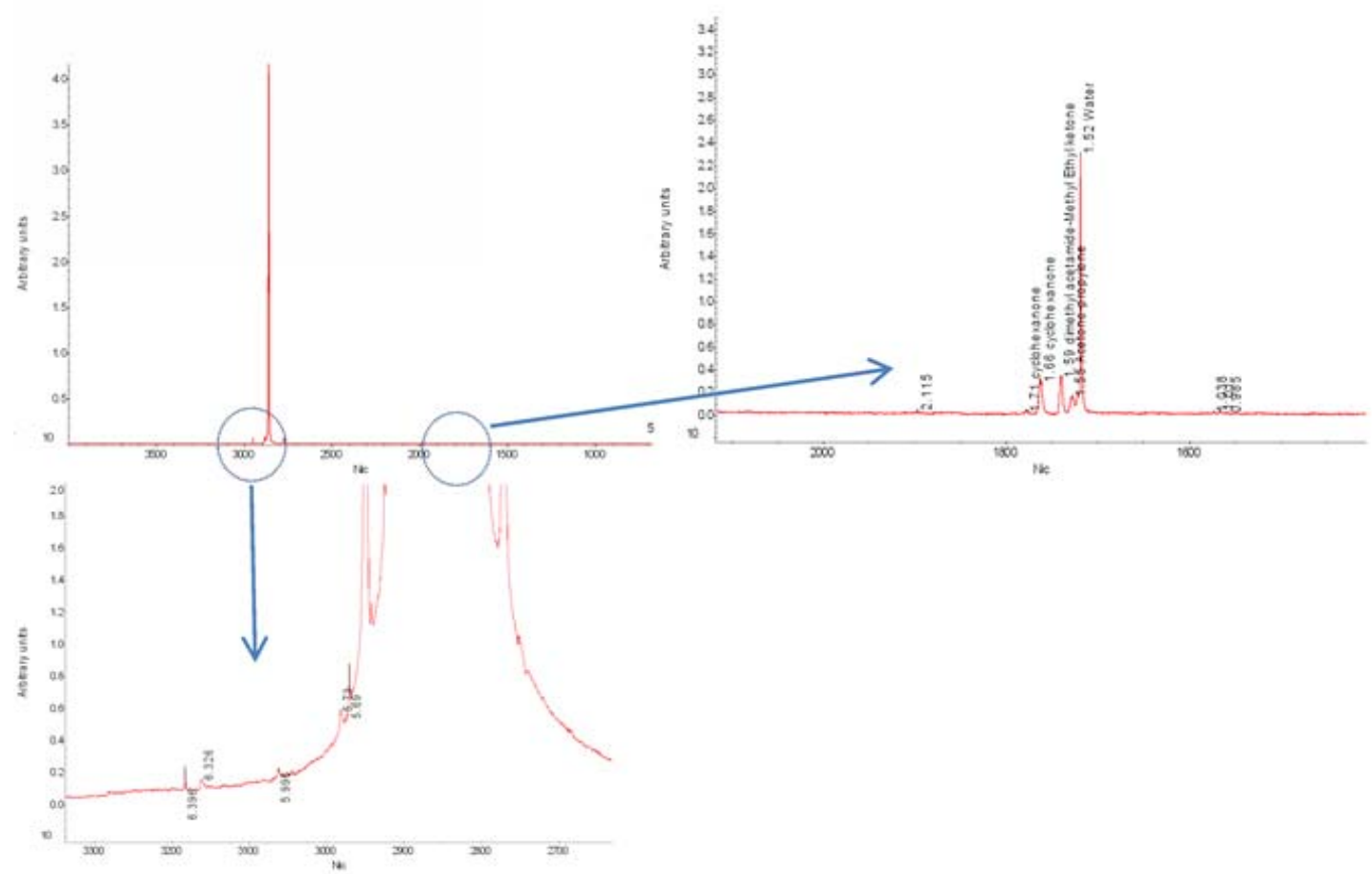

Figure 3-3. NMR Spectrum of Impurities Present in Methylene Chloride Extractant

Degradation of all of these organic components is feasible. The degradation of select internal standards and surrogates, specifically the nitrous acid induced decomposition of phenol-d6 and perylene-d12, primarily led to the formation of alcohols reported for the surface Tank 50 acidified extracts. The level of alcohols generated was much lower than that of the materials destroyed. Approximately $150 \mathrm{mg} / \mathrm{L}$ of lab standards were degraded, and less than $20 \mathrm{mg} / \mathrm{L}$ of alkyl alcohols were formed.

\subsection{Other Considerations}

Isooctyl adipate reported in earlier quarterly samples does not appear to be related to the organics generated by acidification of the tank waste sample. The adipate is a more highly functionalized molecule, which is a known industrial plasticizer. Adipate was identified in only two of the recent Tank 50 quarterly samples. ${ }^{4,5}$ 


\subsection{Conclusions}

The source of reported alcohols formed from the acidification process was most likely the result of the surrogate and internal standards added to the sample extract. These materials all have aromatic structures, ranging in size from phenol-d6 $\left(\mathrm{C}_{6} \mathrm{D}_{6} \mathrm{O}\right)$ to perylene-d12 $\left(\mathrm{C}_{20} \mathrm{D}_{12}\right)$. This has been shown by the preparation of a matrix matched blank, extracted at caustic, neutral, and acidic $\mathrm{pH}$. When the blank is acidified to $\mathrm{pH}$ 2, the resulting extract contains degradation products comparable to those found in recent Tank 50 extracts. Contaminants were found in four different quarterly samples, ${ }^{5,6,7,8}$ but reported in only two quarterly reports before the true source of the material was uncovered. ${ }^{5,6}$

The degradation products probably are formed through the action of nitrous acid upon the surrogate or internal standards present in the sample extract. Nitrous acid is a strong oxidizer and is formed when sodium nitrite in the sample matrix is acidified to less than $\mathrm{pH} 2$.

\subsection{Recommendations and Path Forward}

The following extraction protocol, lab blanks, and peer review will be implemented for all future quarterly Tank 50 WAC samples.

Extraction Protocol - All Tank 50 sample extractions will be performed as received (with no pH adjustment), and then, for the sole purpose of analyzing for phenol, re-extracted with sample $\mathrm{pH}$ adjusted to $\mathrm{pH}$ 7. The "as received", then neutralized extraction will be carried out for each sample and blank each quarter, and extracts will be analyzed separately.

Lab Blanks - A matrix matched blank will be prepared and analyzed in addition to the laboratory extraction blank and customer supplied blank received with samples each quarter. All will receive preparative chemistry identical to the samples, including neutralization, spike, and extraction.

Peer Review - An independent technical review shall be performed on $100 \%$ of the analyses. 


\subsection{References}

1. Crump, S. L., “Determination of Method Reporting Limits for Select Analytes by GC/MS,” SRNLTR-2010-00206, Rev. 0, Savannah River National Laboratory, Aiken, SC 29808 (2010).

2. Slovak University of Technology “Organic Chemistry,” Fourth Edition: e-Text, p. 943.

3. Hickenbottom, Wilfred J., “Reactions of Organic Compounds, Third Edition” p. 148-149.

4. C. J. Bannochie, "Results for the Third Quarter 2012 Tank 50 WAC Slurry Sample: Chemical and Radionuclide Contaminants,” SRNL-STI-2012-00621_3Q12-WAC_Rev 0, Savannah River National Laboratory, Aiken SC 29808 (2012).

5. C. J. Bannochie, "Results for the Fourth Quarter 2012 Tank 50 WAC Slurry Sample: Chemical and Radionuclide Contaminants,” SRNL-STI-2012-00786_4Q12-WAC_Rev 0, Savannah River National Laboratory, Aiken SC 29808 (2013).

6. C. J. Bannochie, "Results for the Third Quarter 2013 Tank 50 WAC Slurry Sample: Chemical and Radionuclide Contaminants,” SRNL-STI-2013-00651_3Q13-WAC_Rev 0, Savannah River National Laboratory, Aiken SC 29808 (2013).

7. C. J. Bannochie, "Results for the Fourth Quarter 2013 Tank 50 WAC Slurry Sample: Chemical and Radionuclide Contaminants,” SRNL-STI-2013-00074_4Q13-WAC_Rev 0, Savannah River National Laboratory, Aiken SC 29808 (2014).

8. C. J. Bannochie, "Results for the First Quarter 2014 Tank 50 WAC Slurry Sample: Chemical and Radionuclide Contaminants,” SRNL-STI-2014-00203_1Q14-WAC_Rev 0, Savannah River National Laboratory, Aiken SC 29808 (2014). 
Distribution:

\begin{tabular}{|c|c|c|c|}
\hline Name: & Location: & Name: & Location: \\
\hline P. M. Almond & 773-43A & M. J. Mahoney & 766-H \\
\hline C. J. Bannochie & $773-42 A$ & S. L. Marra & 773-A \\
\hline M. J. Barnes & 773-A & D. J. Martin & $241-246 \mathrm{H}$ \\
\hline J. M. Bricker & 704-30S & D. H. McGuire & 999-W \\
\hline L. W. Brown & 773-A & P. W. Norris & $704-Z$ \\
\hline T. B. Brown & 773-A & F. M. Pennebaker & $773-42 \mathrm{~A}$ \\
\hline N. F. Chapman & 766-H & M. M. Potvin & $704-27 \mathrm{~S}$ \\
\hline C. K. Chiu & $704-30 S$ & J. W. Ray & $704-27 S$ \\
\hline L. H. Connelly & 773-A & S. H. Reboul & $773-42 \mathrm{~A}$ \\
\hline J. S. Contardi & 766-H & M. M. Reigel & $773-42 \mathrm{~A}$ \\
\hline A. D. Cozzi & 999-W & L. B. Romanowski & 766-H \\
\hline C. C. DiPrete & 773-A & A. R. Shafer & $704-27 S$ \\
\hline D. B. Dixon & $705-1 C$ & C. B. Sherburne & $707-7 \mathrm{E}$ \\
\hline E. J. Freed & $704-S$ & D. C. Sherburne & $704-S$ \\
\hline J. C. Griffin & 773-A & F. M. Smith & $705-1 C$ \\
\hline E. W. Harrison & $704-60 \mathrm{H}$ & M. E. Smith & 704-30S \\
\hline P. J. Hill & 766-H & B. A. Speight & 707-7E \\
\hline E. N. Hoffman & 999-W & A. V. Staub & $241-119 \mathrm{H}$ \\
\hline J. F. Iaukea & $704-27 S$ & S. A. Utlak & $704-27 S$ \\
\hline P. R. Jackson & $703-46 \mathrm{~A}$ & J. R. Vitali & 766-H \\
\hline V. Jain & $704-Z$ & T. L. White & 773-A \\
\hline C. A. Langton & 773-43A & A. W. Wiggins & $241-168 \mathrm{H}$ \\
\hline J. N. Leita & 704-30S & R. H. Young & 773-A \\
\hline K. R. Liner & $704-S$ & & \\
\hline
\end{tabular}

